\title{
Settlement of reactive power compensation in the light of white certificates
}

\author{
Konrad Zajkowski ${ }^{1, *}$ \\ ${ }^{1}$ Koszalin University of Technology, DP of Energy, 15-17 Raclawicka St. 75-620 Koszalin, Poland
}

\begin{abstract}
The article discusses the problem of the determination of savings on active energy as a result of a reactive power compensation. Statutory guidance on the required energy audit to obtain white certificates in the European Union was followed. The analysis was made on the basis of the Polish Law. The paper presents a detailed analytical method and an estimation method taking into account the impact on the line, the transformer and the generator. According to the relevant guidelines in the European Union, the reduction of $\mathrm{CO}_{2}$ emissions by calculating the saving of active power should be determined.

The detailed method and an estimation method proposed for the determination of savings on active energy as a result of the reactive power compensation carried out possess some errors and inconvenience. The detailed method requires knowledge of the network topology and a determination of reactive power $Q$ at each point of the network. The estimation method of analysis is easy in execution, especially if the consumer of energy is the main or the most significant purchaser of electricity in the network. Unfortunately, this latter method can be used only for activities that do not require high computational accuracy. The results obtained by this method are approximate values that can be used for the calculation of economic indicators. The estimation method is suitable for determining the number of white certificates when a power audit concerns a recipient of electricity, the structure of which is a large number of divisions scattered at many different locations in the power system.
\end{abstract}

\section{Introduction}

In Europe, the white certificates are a market tool for improving energy efficiency. This is document demonstrating energy savings as a result of investments to improve energy efficiency.

The investments that reduce the production of electricity, which reduces the negative impact on the environment is one of activities. An energy audit is an element that makes the settlement of the actions undertaken possible. The relevant guidelines are set out in the following regulations: [1-6].

Among the many energy efficiency improvement measures [7] that make it possible to apply for white certificates, is to limit the flow of reactive power [2]. This action consists in performing size electrical measurements and analysing the location of the compensation devices.

The subject of energy savings is active energy, which is saved by the action of reducing the flow of reactive energy. The effect of reducing the reactive power is to reduce the active power in the form of energy losses on the power grid.

An engineering approach in this area will involve a determination of savings on primary energy (individually on each grid element) being the result of reducing reactive power flows.

\section{Methodology}

An analysis in a detailed and simplified audit should be prepared by means of the balance method [2]. It is important to analyze the components in the energy distribution system by selecting the shortest route connecting the generator to the power compensation location.

Two calculation methods will be presented: detailed (sections $2.1-2.4$ ) and estimation (sections 2.5 - 2.6). In section 3 , a computational example using the estimation method proposed by the author is presented.

\subsection{Transmission line section}

Reactive power flows through a line segment cause:

- a limitation of the active power transfer,

- an increase of active power losses,

- an increase of current and voltage drops,

- difficulties in the work of grid elements.

The transmission line can be described with impedance $R+\mathrm{j} X$. This approach was presented by the authors in the following positions: [8-13].

The active power $P$ is absorbed by the receiver (Fig. 1), and for the reactive power $Q$, the receiver is a prosumer (receiver or supplier). Both the active and reactive power generated by the receiver affect

* Corresponding author: konrad.zajkowski@tu.koszalin.pl 


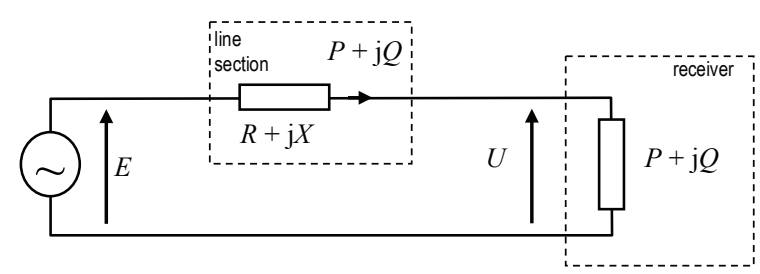

Fig. 1. Mathematical model of the section of the power line.

the $\Delta P$ power losses on the $R+\mathrm{j} X$ impedance:

$$
\Delta P=\frac{P^{2}+Q^{2}}{U^{2}} R .
$$

When the compensator is added (Fig. 2), the reactive power passing through the line is reduced.

$$
Q^{\prime}=Q-Q_{C}
$$

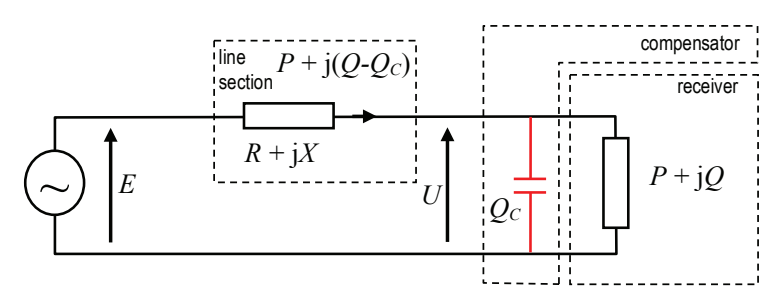

Fig. 2. Mathematical model after compensation.

Typically, this power is not reduced to zero. With partial compensation, the remaining reactive power continues to load the flow. The difference between the active power loss (1) determined prior $\Delta P$ and after $\Delta P^{\prime}$ compensation is a profit on $\delta P_{P}$ active power:

$$
\delta P_{P}=\Delta P-\Delta P^{\prime}=\frac{2 Q Q_{C}-Q_{C}^{2}}{U^{2}} R, \quad \delta A_{P}=\delta P_{P} \cdot T_{p},
$$

where: $Q_{C}$ - power of compensator, $\delta A_{P}$ - active energy, $T_{p}-$ work time of compensator $Q_{C}$.

In the $m^{\text {th }}$ section of the transmission line, the loss of active power is dependent on the power transmitted by the next line section (Fig. 3):

$$
\delta P_{P(m)}=\frac{Q_{(m+1)}^{2}-Q_{(m+1)}^{\prime 2}}{U_{(m)}^{2}} R_{(m)}
$$

where: $Q_{(m+1)}$ - reactive power transmitted from $m+1$ system, $Q^{\prime}{ }_{(m+1)}$ - reactive power from $m+1$ system after switching on the compensator in the receiver.

The reactance in the $m+1$ section changes the reactive power acting on the $m^{\text {th }}$ section. Analogically, the reactive power is changed after the compensation $Q^{\prime}$.

Due to the variability of the parameters over time, the values given in formulas (3) and (4) are values averaged over the $T_{p}$ time interval. To determine the economic profit resulting from the compensation should be known:
- network topology,

- the length of the $m^{\text {th }}$ section of the line,

- the conductor cross-section area,

- the conductivity of the conductive material,

- reactive power before $Q_{(m)}$ and after $Q_{(m)}^{\prime}$ the compensation.

Unfortunately, for all network elements this data is often not available.

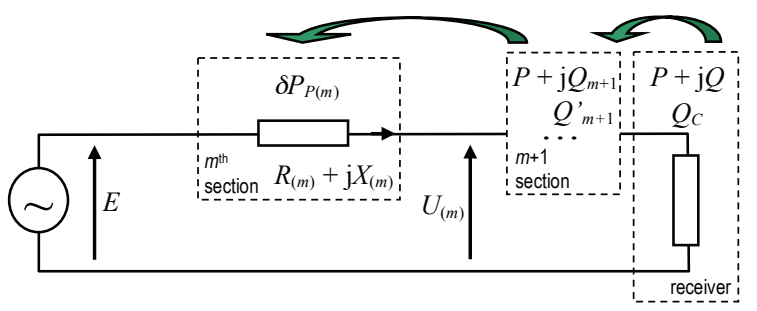

Fig. 3. Impact between network segments.

\subsection{The transformer}

The transformer for the power line is the $R_{T}$ resistance at which the loss of active power takes place. This loss is described in formula (1). Reactive power flows through the transformer cause an increase of active power losses in the transformer. Load losses $\Delta P_{o T}$ in a three-phase transformer are the result of the flow of current $I$ through the winding:

$$
\Delta P_{o T}=3 I^{2} R_{T}
$$

When the current is equal to the $I_{n T}$ nominal current, the load losses will be:

$$
\Delta P_{o n T}=3 I_{n T}^{2} R_{T}
$$

From equations (5) and (6), a relationship is obtained which allows the loss to be measured at any transformer load:

$$
\Delta P_{o T}=\Delta P_{o n T}\left(\frac{I}{I_{n T}}\right)^{2}=\Delta P_{o n T}\left(\frac{S}{S_{n T}}\right)^{2},
$$

where from the transformer's datasheet: $\Delta P_{o n T}-$ nominal load power dissipation, $S_{n T}-$ nominal power of the transformer.

The savings on the active power losses in the $m^{\text {th }}$ transformer using the reactive power compensation in the receiver equals the loss difference before and after the compensation:

$$
\delta P_{T(m)}=\Delta P_{o n T(m)}\left(\frac{Q_{(m+1)}^{2}-Q_{(m+1)}^{\prime 2}}{S_{n T(m)}^{2}}\right) .
$$

Thus, the gain on active energy in the $m^{\text {th }}$ transformer is:

$$
\delta A_{T(m)}=\delta P_{T(m)} \cdot T_{p} .
$$

The parameters $Q_{(m+1)}$ and $Q_{(m+1)}^{\prime}$ in formula (8) is to be understood as reactive power at the output of the 
preceding segment, which may be another transformer or preceding a power line segment (same as shown in Fig. $3)$.

In chapters 2.1 and 2.2, the change in active power caused by the impact of individual sections of the power system (transformer or line segment) has been omitted. These chapters also omit the change in the voltage value $U_{(m)}$ that occurs when the compensator is connected.

\subsection{The generator}

The effect of reactive power from the segment preceding the generator, causes a reduction the ability to produce active power. When the power factor is less than nominal, it is impossible to use the full power of the turbine due to the thermal load of the generator. An increased reactive power flow causes a demagnetization of the rotor and a reduction of the electromotive force of the generator.

In the case of asynchronous generators, reactive power must be supplied from the network or from the compensator with an individual compensation.

In practice it is difficult to estimate the demand for reactive power of each segment in the power system. Due to the existence of the reactance of individual section in the system, reactive power is required and can't be completely zero.

To determine the influence of power in the generator is the use of similarities in electrical properties between the transformer and the generator.

$$
\delta A_{G}=\delta P_{G} \cdot T_{p}=\Delta P_{o n G}\left(\frac{Q_{(m+1)}^{2}-Q_{(m+1)}^{\prime 2}}{S_{n G}^{2}}\right) T_{p} .
$$

where: $\Delta P_{o n G}-$ load losses at a nominal current flow through the generator, $S_{n G}$ - nominal power of the generator.

The production costs of reactive power in generators are substantially smaller than in receivers. However, the production of reactive power in the generator increases the transmission costs of reactive power in the network. Therefore, from an economic point of view, the production of reactive power in the generator and its transmission to customers is unprofitable.

\subsection{Energy savings in all system segments}

Energy saving $\delta A$ that results from the reduction of active power losses in all the parts of the network by using the reactive power compensation of the receiver requires knowledge of the network topology and the determination of (4), (8) and (10):

$$
\delta A=\delta A_{G}+\sum_{m}\left(\delta A_{P(m)}+\delta A_{T(m)}\right) .
$$

Determination of value (11) requires:

- knowledge of network topology,

- measurement of $Q_{(m)}$ power at each point of the network,

- knowledge of the change in reactive power $Q_{(m)}^{\prime}$ caused by the $Q_{C}$ power compensation in the receiver.

This information is not available for every point in the network. In practice, the reactive power $Q_{(m)}^{\prime}$ can't be measured. The powers $Q_{(m)}$ and $Q_{(m)}^{\prime}$ can be determined analytically, but this requires detailed information about the entire network.

\subsection{The energy equivalent of reactive power}

Inclusion in the calculations of additional current flows, ie: a complete power grid structure with several generators and multiple receivers, results in additional computational complexity calculations.

A solution to this problem might be the use of the ratio (Fig.4) which was determined in the mid twentieth century: the energy equivalent of reactive power [14-16]. This ratio is defined as the differential of the active power losses in relation to reactive power.

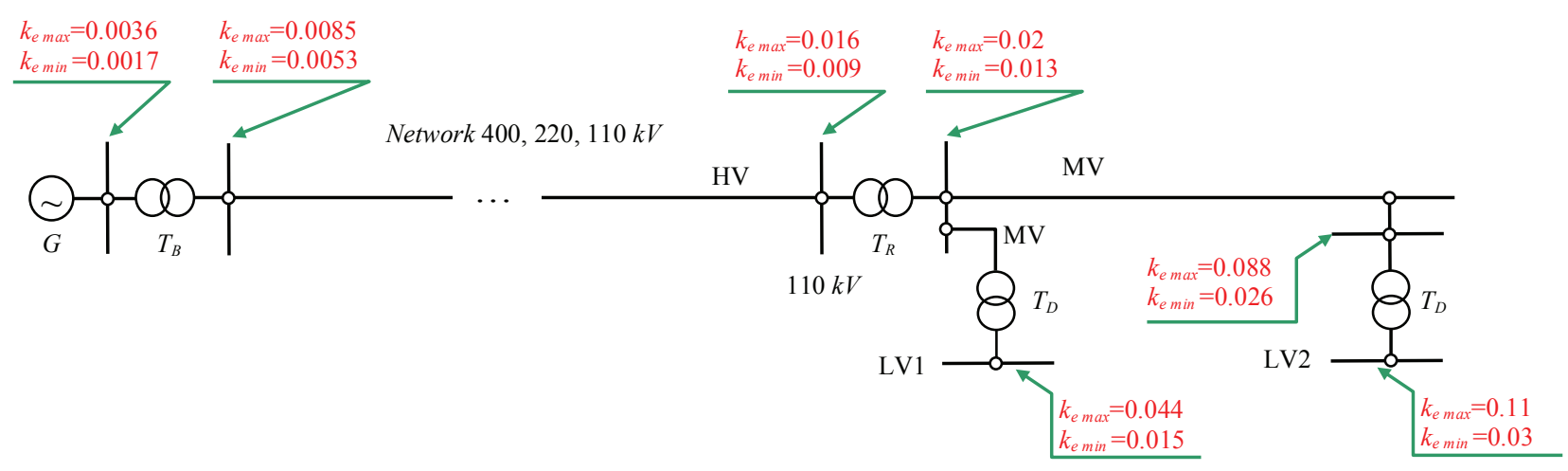

Fig. 4. The values of the energy equivalent of reactive power estimated in 2007 [7]. 


$$
k_{e}=\frac{\delta}{\delta Q} \Delta P=\frac{2 Q}{U^{2}} R \quad\left[\frac{k W}{k V A r}\right]
$$

The value of coefficient $k_{e}$ strongly depends on reactive power, and it varies with changes to this power. This quantity permits one to calculate the change of active power losses caused by changes to reactive power that is collected at a given point in the network. The value of this factor depends from the value of reactive power and the distance of the point analyzed to source, whose measure is resistance $R$. According to the literature [9] and [12], the value of this coefficient is determined for the minimum and maximum reactive power loads (Fig.4).

Due to the variability of the load, the average value of the reactive power energy equivalent in a given network node is accepted in calculations:

$$
k_{e a \mathrm{vg}}=\frac{k_{e \min }+k_{e \max }}{2} .
$$

In order to estimate how much power losses are reduced in the grid that supplies a given network point as a result of the installation of a battery of condensers, it is enough to multiply the value of the reactive power energy equivalent for this point by the power of the battery installed.

The reduction amount of losses is calculated from the following formula:

$$
\delta P=k_{\text {eavg }} \cdot Q_{C}, \quad \delta A=\delta P \cdot T_{p} .
$$

The equivalent of reactive power $k_{e}$ is an economic tool. It is an indicator approximating many of the phenomena discussed in sections $2.1-2.4$ (only the most important has been discussed). Using this factor, the calculations are error-prone, the value of which depends on the accuracy of the determination of $k_{e}$.

The value of the energy equivalent of reactive power $k_{e}$ depends from the following:

- the distance of the point analyzed in the network (the resistance path from the generator to the point analyzed in the network),

- the load of the network - an adoption of the arithmetic average of the minimum and maximum values is only a partial correction of an error in estimation,

- network topology and its complexity.

This means that an estimation of the reduction of losses based on the energy equivalent of reactive power is burdened with significant errors. The latest $k_{e}$ values are the result of random testing for a limited part of the power system and were performed in 2007 [7].

Due to considerable computational uncertainty, this coefficient allows you to know only the range of power values. However, there are situations where the use of this indicator is necessary. For example, when you need to designate economic indicators that account for the installation of compensator that are connected to the network and:
- the exact structure of the network is unknown,

- it is not possible to count the currents and energy losses on individual network segments (see section 2.4),

- an economic task involving a very large number of recipients.

Approximate results are obtained when the $k_{e}$ coefficient is used, so this calculation will be referred to as estimation method. Comprehensive calculations for each network member (see section $2.1-2.4$ ) will be referred to as detailed analytical method.

\subsection{Determination of primary energy savings}

Determination of primary energy savings is needed to account for the economic effects of improving energy efficiency. It is possible to apply for white certificates, which are awarded by tender. They are documents that weigh actions to improve the energy efficiency of company's or state.

The saved active energy is prepared for one calendar year by making adequate measurements and calculations [2]. The values of the average energy determined in billing invoices can be used as input data. This can be determined when using advanced electronic energy meters, which possess separate individual records with a division into inductive and capacitive reactive power. For this purpose, it is best to accept the entire billing year in an analysis, including all the seasons, and which consists of $i$-billing periods.

When the estimation method is used, only inductive reactive power can be used, since the $k_{e}$ coefficient is determined only for such power. Prior to compensation, the average power factor for inductive reactive power is:

$$
\tan \varphi(i)=\frac{A_{Q(i)}}{A_{P(i)}}
$$

where: $A_{Q}$ - total inductive reactive energy read from the $i^{\text {th }}$ invoice, $A_{P}$ - consumed active energy during this period.

The value of $\tan \varphi^{\prime}$ after the compensation can be determined in two ways:

a) when there are invoices from the period after the compensation, this coefficient is calculated analogously to (15).

b) when there is no invoice after the compensation (settlement made before the compensator is enabled), the minimum value (e.g. 0.4) from contract, should be taken.

Assuming invariable active energy, after partial compensation there is still reactive energy, which is:

$$
A_{Q(i)}^{\prime}=\tan \varphi^{\prime} \cdot A_{P(i)}
$$

Therefore, reactive power reduced by the compensator in the $i^{\text {th }}$ billing period is equal to:

$$
A_{C(i)}=Q_{C} \cdot T_{p}=A_{Q(i)}-A_{Q(i)}^{\prime} .
$$


It is reactive inductive energy reduced by the battery of capacitors.

Taking the energy equivalent of reactive power determined for the point being the closest to compensation according to (14), the value of active power reduction in the network caused by compensation $A_{C}$ in the $i^{\text {th }}$ billing period is as follows:

$$
\delta A_{(i)}=k_{\text {e avg }} \cdot A_{C(i)} .
$$

Taking invoices for the whole year, the total final energy savings (within the meaning of the Act [1]) constitute the sum of active energy savings resulting from compensation:

$$
\delta A=\sum_{i} \delta A_{(i)} \quad[k W h / \text { year }] .
$$

In accordance with the guidelines of the International Energy Agency (IEA) and the Organisation for Economic Co-operation and Development (OECD), the value of (19) expressed in the tons of oil equivalent (toe) is:

$$
\delta A_{\text {toe }}=\frac{\delta A}{11630} \quad[\text { toe } / \text { year }]
$$

The average annual primary energy savings referred to in [1] in accordance with [2] are equal to:

$$
\delta A_{p}=\delta A \cdot w_{i}, \quad \delta A_{p t o e}=\delta A_{\text {toe }} \cdot w_{i}
$$

where: $\delta A_{p}$ - the amount of primary energy savings expressed in primary fuel $[\mathrm{kWh} /$ year $]$ or $[G J /$ year $], \delta A$ - final energy savings, expressed in $[\mathrm{kWh} /$ year $]$ or $[\mathrm{GJ} /$ year $], w_{i}$ - effort ratio of non-renewable primary energy which depends from the final energy carrier (Tab.1).

The $w_{i}$ factor is defined according to the fuel or energy source used in a given country, which according to [4] should be one of the values:

Table 1. Effort ratio of non-renewable primary energy for the production and supply of electric energy.

\begin{tabular}{|l|c|}
\hline \multicolumn{1}{|c|}{ Way of producing electricity } & $w_{i}$ \\
\hline \hline mixed-mode production & 3.0 \\
\hline production of electricity from solar energy & 0.7 \\
\hline
\end{tabular}

For a specified value of $\delta A_{p}$ expressed in [ $\mathrm{kWh} /$ year $]$, the reduction of $\mathrm{CO}_{2}$ emissions in a year is determined according to [5]:

$$
\Delta E_{\mathrm{CO} 2}=\delta A_{p} \cdot 3.6 \cdot 10^{-3} \cdot w e_{\mathrm{CO}_{2}}[\mathrm{~kg} / \text { year }] \text {, }
$$

where: $w_{\mathrm{CO}_{2}}-\mathrm{CO}_{2}$ emission factor for fuels.

The quantity of the reduction of $\mathrm{CO}_{2}$ emissions is calculated using $\mathrm{CO}_{2}$ emission factors contained in [5] and under the EU Emissions Trading System (EU ETS) for a given year (Table 2).
Table 2. Example $w_{\mathrm{CO} 2}$ reference $\mathrm{CO}_{2}$ emission factors for fuels [6] in accordance with the guidelines of the Intergovernmental Panel on Climate Change (IPCC) from the year 2006.

\begin{tabular}{|l|c|l|c|}
\hline \multicolumn{1}{|c|}{ Fuel type } & $\begin{array}{c}w e_{\mathrm{CO} 2} \\
\mathrm{MgCO}_{2} / \mathrm{TJ}\end{array}$ & \multicolumn{1}{|c|}{ Fuel type } & $\begin{array}{c}w e_{\mathrm{CO} 2} \\
\mathrm{MgCO}_{2} / \mathrm{TJ}\end{array}$ \\
\hline \hline petroleum & 73.3 & coking coal & 94.5 \\
\hline shale oil & 73.3 & lignite & 101.1 \\
\hline gas / diesel oil & 74.0 & bituminous coal & 94.2 \\
\hline ethane & 61.6 & natural gas & 56.1 \\
\hline solvent naphtha & 73.3 & industrial waste & 142.9 \\
\hline petroleum coke & 97.5 & waste oils & 73.3 \\
\hline refinery gas & 51.3 & peat & 105.9 \\
\hline
\end{tabular}

A project aimed at an improvement of energy efficiency, as a result of which energy savings in (21) are obtained in an amount being an equivalent to at least 10 toe on average over the year, can be included in a tender [1]. Several projects of the same type aimed at an improvement of energy efficiency, as a consequence of which the total energy savings are achieved in the amount being an equivalent to at least 10 toe on average over a year, may be brought together.

\section{Results}

The proposed calculation method using $k_{e}$ factor, which the author called the estimation method, was used to designate white certificates for one Polish company. This economic settlement covered some 350 branches subordinate to the company, in which the reactive power

\begin{tabular}{|c|c|c|c|c|c|c|c|}
\hline \multirow{3}{*}{$i$} & \multirow{3}{*}{ 密 } & & & & & & \\
\hline & & \multirow{2}{*}{$\begin{array}{l}A_{P(i)} \\
\mathrm{kWh}\end{array}$} & \multirow{2}{*}{$\begin{array}{c}A_{Q(i)} \\
\text { kVArh }\end{array}$} & \multirow{2}{*}{$\begin{array}{c}\tan \varphi_{(i)} \\
\mathrm{VAr} / \mathrm{W}\end{array}$} & \multirow{2}{*}{$\begin{array}{c}A_{Q(i)}^{\prime} \\
\text { kVArh }\end{array}$} & \multirow{2}{*}{$\begin{array}{c}A_{C(i)} \\
\text { kVArh }\end{array}$} & \multirow{2}{*}{$\begin{array}{l}\delta A_{(i)} \\
\mathrm{kWh}\end{array}$} \\
\hline & & & & & & & \\
\hline 1 & 61 & 204862 & 174510 & 0.852 & 81945 & 92565 & 6480 \\
\hline 2 & 60 & 18 & 171452 & 931 & 1 & 97 & 6846 \\
\hline 3 & 61 & 189452 & 185 & 0.979 & 757 & 109642 & 7675 \\
\hline 4 & 61 & 208512 & 160214 & 768 & 83405 & 76809 & 5377 \\
\hline 5 & 61 & 210245 & 182134 & 0.866 & 84098 & 98036 & 6863 \\
\hline 6 & 61 & 195428 & 181247 & 0.927 & 78171 & 103076 & 7215 \\
\hline$\sum$ & 365 & 1192627 & 1054980 & & & 577929 & 40455 \\
\hline
\end{tabular}
compensation was made. These calculations has been checked and reviewed. White certificates have been awarded to this company.

Table 3. Summary values from invoices and calculations.

The computational example presented here concerns one point where reactive power compensation has been made. The settlement was based on 6 invoices that covered the entire calendar year. The $\tan \varphi$ ' coefficient (after the compensation) was assumed to be equal to the contract value, that is 0.4 . This receiver has been connected to a low voltage network (LV2 in Fig.4). The energy equivalent of reactive power is equal: $k_{e \min }=0.03, k_{e \max }=0.11$. It is assumed that the energy consumption in the year in which the company is applying for white certificates will be at a similar level as in the year when meter measurements were conducted. Statements and calculations were made on the basis of invoices from a representative calendar year. The total final energy savings are as follows: 


$$
\delta A=40455 \mathrm{kWh} / \text { year } .
$$

This corresponds to the value expressed in tons of the oil equivalent (20):

$$
\delta A_{\text {toe }}=3.48 \text { toe / year } .
$$

The electricity consumer is connected to the power grid, which is characterized by the production of electricity from renewable and non-renewable sources. In this case (according to Tab.1), $w_{i}$ factor is equal to 3. According to Equation (21), the average annual primary energy savings are:

$$
\delta A_{p}=\delta A \cdot w_{i}=121365 \mathrm{kWh} / \text { year }
$$

in toe: $\quad \delta A_{\text {ptoe }}=\delta A_{\text {toe }} \cdot w_{i}=10.44$ toe $/$ year .

As a result of the foreseen reactive power compensation, the threshold of 10 toe will be exceeded, so the entity can apply for white certificates.

The $\mathrm{CO}_{2}$ emission factor for power plants and combined heat and power plants that use bituminous coal is as follows [5]:

$$
\mathrm{we}_{C O 2}=93.8 \mathrm{~kg} / G J \text {. }
$$

The reduction of $\mathrm{CO}_{2}$ emissions per year (22) is:

$$
\Delta E_{\mathrm{CO} 2}=\delta A_{p} \cdot 3.6 \cdot 10^{-3} \cdot w_{\mathrm{CO}_{2}}=40.98 \text { tons }_{\mathrm{CO}_{2}} / \text { year } .
$$

\section{Discussion and Conclusions}

The proposed two methods of determining the savings of active energy due to the compensation of reactive power have some faults and difficulties. Where the network topology is simple and the measured power values are known at each point in the network, the detailed analytical method may be used. In other cases, a estimation method can be used, which requires the knowledge of the values of $k_{e}$ factor: the energy equivalent of reactive power. The disadvantage of this method is the inaccuracy of calculations, which is dependent from the error in the determination of $k_{e}$ coefficient, but in economic calculations, which the purpose is to know the approximate value of the power saved, such a calculation is acceptable.

When considering a recipient of electricity with a large number of divisions scattered in many different places in the power system, so far no computational energy audit has been developed. In these cases, no electricity audits were made. The author of this article has consulted experts from several countries in Europe. Only Italians performed such audits, but in calculations they limited themselves to analysing the last segment of the electricity network - between the meter and the receiver.

By using the estimation method, the author performed two power audits in 2014 and 2016. The calculations concerned one of Polish companies dealing with the sale of automotive fuels. Both audits have passed a positive review in the Ministry and have been granted white certificates.

\section{References}

1. Journal of Laws of the Republic of Poland (Dz.U. 2011 r. Nr 94, poz. 551 z późn.zm.), Ustawa o efektywności energetycznej

2. Journal of Laws of the Republic of Poland (Dz.U. 2012 r. poz. 962), Rozp. Ministra Gosp. w sprawie szczegółowego zakresu $i$ sposobu sporzadzania audytu efektywności energetycznej

3. Journal of Laws of the Republic of Poland (Dz.U. z 2012 r. poz. 1039), Rozp. Ministra Gosp. wsprawie sposobu obliczania ilości energii pierwotnej odpowiadającej wartości świadectwa efektywności energetycznej

4. Journal of Laws of the Republic of Poland (Dz.U. $\mathrm{Nr} 201$ z 2008r. poz. 1240), Rozp. Ministra Infrastr. $w$ sprawie metodologii obliczania charakt. energet. budynku i lokalu mieszkalnego lub części budynku

5. Journal of Laws of the Republic of Poland (Dz.U Nr 183 z 2008 r. poz.1142), Rozp. Ministra Środow. w sprawie sposobu monitorowania wielkości emisji substancji objętych wspólnotowym systemem handlu uprawnieniami do emisji

6. Ministry of Environment, Wartości opałowe (WO) $i$ wskaźniki emisji CO2 (WE) w roku 2009 do raportowania $w$ ramach Wspólnotowego Systemu Handlu Uprawnieniami do Emisji za rok 2012, http://www.mos.gov.pl/

7. R. Kołodziej, Elektroenergetyka 11-12 1-2, 119-127 (2012)

8. W. Szpyra, Straty Energii Elektrycznej w Sieciach Elektroenergetycznych, p. 59-69, Poland (2008)

9. S. Duer, K. Zajkowski, I. Płocha, R. Duer, Neural Comput. Appl. 22, 7-8, 1581-1590 (2013) DOI: $10.1007 / \mathrm{s} 00521-012-1052-9$

10. S. Duer, K. Zajkowski, Neural Comput. Appl. 23, 78, p. 2185-2197 (2013) DOI: 10.1007/s00521-0121169-x

11. K. Zajkowski, Neural Comput. Appl. 24, 2, p.431439 (2014) DOI: 10.1007/s00521-012-1239-0,

12. K. Zajkowski, S. Scaticailov, Nonconventional Technol. Rev. 6 XX, 2, 54-61, (2016)

13. J. Smyczek, K. Zajkowski, EUROSIS-ETI, p. 278281, Univ. of Malaga, Spain (2004)

14. M. Kuchta, M. Siergiejczyk, J. Paś, JVE Int. Ltd. J. Vibroeng. 16, 8, 4039-4044 (2014)

15. W. Szpyra, Przegląd Elektrotechniczny 2, 144-147, (2011)

16. I. Coroama, M. Gavrilas, I. Ovidiu, Politehnica University of Timisoara, Romania (2010) 